\title{
Expression of seed vigor and initial growth of red clover under fungicide influence
}

\author{
Carolina Cipriano Pinto ${ }^{1}$, Lucian Alex dos Santos ${ }^{1}$, Eduardo Gonçalves Borges ${ }^{1}$, Carina Oliveira e Oliveira ${ }^{2}$, \\ Carlos Eduardo da Silva Pedroso ${ }^{1}$, Tiago Zanatta Aumonde ${ }^{1}$ \\ ${ }^{1}$ Universidade Federal de Pelotas - UFPel, Faculdade de Agronomia Eliseu Maciel, Departamento de Fitotecnia e área \\ de Ciência e Tecnologia de Sementes. ${ }^{2}$ Universidade de São Paulo - USP, Escola Superior de Agricultura Luiz de Queiroz \\ - ESALQ. Departamento de Fitotecnia e área Sementes. E-mail: lucian.agronomo@gmail.com
}

\begin{abstract}
The objective of this study was to evaluate the expression of seeds vigor and physiological performance of initial growth of red clover plants under the influence of fungicide doses of carboxin + thiram. Three lots of seeds were used (high; medium and low vigor) treated with 0; 150; 250 fungicide doses and $350 \mathrm{~mL}$ i.a./100 $\mathrm{kg}$ of seeds. Germination, first count, emergence, speed index of seedling emergence, length and dry matter of shoot and root, leaf area and shoot/root ratio were evaluated. The experimental design was completely randomized in a factorial $3 \times 4$ (three lots - high, medium and low vigor $x$ four fungicide doses of carboxin + thiram). Data were submitted to analysis of variance and if significant at $5 \%$ probability, adjusted for orthogonal polynomials. It was possible to observe that there were significant differences for the means of the variables germination, first germination count, emergency, emergency speed index, shoot length, root length, aerial part dry mass, root dry mass, leaf area, leaf area ratio and shoot and root ratio. The fungicide doses of 150 to $350 \mathrm{~mL}$ i.a./100 kg of seeds result in greater seedling emergence, higher leaf area ratio and increased shoot/root ratio in plants from lots of medium vigor seeds. The fungicide consisted of carboxin + thiram enhances the expression of seed vigor and physiological performance of seedlings growth derived from lots of medium vigor seeds.
\end{abstract}

Keywords: initial performance; forage; treatment; Trifolium pratense $\mathrm{L}$.

\section{Expressão do vigor de sementes e crescimento inicial de trevo vermelho sob influência de fungicida}

\section{Resumo}

O objetivo deste trabalho foi avaliar a expressão do vigor de sementes e o desempenho fisiológico de crescimento inicial de plantas de trevo vermelho submetidas à influência de doses de fungicida à base de carboxin + thiram. Foram utilizados três lotes de sementes (alto; médio e baixo vigor) tratadas com as doses de fungicida 0; 150; 250 e $350 \mathrm{~mL}$ i.a./100 kg de sementes. Foram avaliados a germinação, primeira contagem, emergência, índice de velocidade de emergência de plântulas, comprimento e matéria seca de parte aérea e de raiz, área foliar, razão de parte aérea e raiz. $O$ delineamento experimental utilizado foi inteiramente casualizado, em esquema fatorial $3 \times 4$ (três lotes - alto, médio e baixo vigor $\times$ quatro doses fungicidas de carboxin + tiram). Os dados foram submetidos à análise de variância e se significativos a $5 \%$ de probabilidade, foram ajustados para polinômios ortogonais. De acordo com os resultados foi possível observar que houve diferença significativa para as médias das variáveis germinação, primeira contagem de germinação, emergência, índice de velocidade de emergência, comprimento de parte aérea, comprimento de raiz, massa seca de parte aérea, massa seca de raiz, área foliar, razão de área foliar e razão de parte aérea e raiz. As doses de fungicida 150 a $350 \mathrm{~mL}$ i.a./100 kg de sementes resultam na maior emergência de plântulas, superior razão de área foliar e incremento na razão parte aérea e raiz em plântulas originadas de sementes de lotes com médio vigor. O fungicida a base de carboxin + thiram realça a expressão do vigor de sementes e o desempenho fisiológico de crescimento de plântulas originadas de lotes de sementes de médio vigor.

Palavras chave: desempenho inicial; forrageira; tratamento; Trifolium pratense L. 


\section{Introduction}

Red clover (Trifolium pratense L.) is widely grown for livestock production due to rusticity, palatability and nutritional content. This species has multiple uses such as cutting, direct grazing, hay and green manure. It can be used in consortium with other plants aiming at feeding on small farms with work-family hand or by dairy cattle farmers (FONTANELI et al., 2012).

Sowing of this family Fabaceae species is performed on surface or in depth of $10 \mathrm{~mm}$ row. Generally, seeds after sowing can be exposed to adverse environmental conditions and susceptible to biotic and abiotic factors, especially during germination and initial seedling growth (PEDÓ et al., 2014). Regarding forages, seed quality does not always reach satisfactory patterns concerning to vigor and health (MARCHI et al., 2011).

Seed chemical treatment consists of synthetic product application in order to avoid losses due to pests and $250 \mathrm{~mL}$ of fungi, allowing a higher emergence and greater seedling performance in field, especially under adverse conditions (BAUDET; PESKE, 2006). Bittencourt et al. (2007) when using 50 and 70 g.a.i.carboxin + thiram fungicide in peanut seed observed a higher percentage of seedlings. Marroni et al. (2012) by working with treatment in castor bean seeds had greater seedling emergence and higher dry matter when using combined $50 \mathrm{~g}$ of carboxin + thiram.

The use of fungicide applied to seeds consists of simple and low-cost method, involving less than $0.5 \%$ of the cost of crop deployment. The used product dose in treatment is variable among species, and the appropriate dosage for a particular genotype will not necessarily be to others and thus should be evaluated for each condition (CARVALHO; NAKAGAWA, 2012). The adequacy of product quantity and evaluation in seed vigor and initial plant growth are assessment tool of plant technical viability for their use in the treatment of seeds in order to protect their initial development of a new plant.

Germination is the resumption of embryo growth, while the effect treats the more subtle aspects of seed quality by involving the reorganization of cellular membrane system, hydrolysis, translocation and allocation of reserves for seedlings, and can be assessed by seedling emergency on substrate (PESKE et al.,
2012). Evaluation of attributes related to germination process of seeds and initial plant growth, allows the determination of different responses of each genotype to different environmental conditions, while the growth assessment is the first step in the interpretation of primary production, adding analysis of leaf area and dry matter (LOPES; LIMA, 2015).

In this context, this study aimed at evaluating the expression of seed vigor and physiological performance of initial growth of red clover plants under fungicide dose influence of carboxin + thiram.

\section{Material and Methods}

The experiment was conducted in the Didactic Laboratory of Seed Analysis and plots of the Department of Plant Science, Graduate Program in Science and Seed Technology of Universidade Federal de Pelotas, at Capão do Leão-RS Campus, situated at latitude $31^{\circ} 48^{\prime} \mathrm{S}$, longitude $52^{\circ} 24^{\prime} \mathrm{W}$ and altitude of $13 \mathrm{~m}$. The climate is characterized as tempered with well distributed rainfall and hot summer of Cfa type according to Köppen classification.

The used red clover cultivar (Trifolium pratense L.) was Estanzuela. Treatments were consisted of lots (high, medium and low vigor) and fungicide doses of carboxin + thiram $(0 ; 150$; 250 and $350 \mathrm{~mL}$ i.a./100 Kg of seeds). The spray volume used was $0.6 \mathrm{~L} 100 \mathrm{~kg}^{-1}$ of seeds for all evaluated doses varying product concentration.

For seed treatment, spray was added to each dose containing fungicide in polyethylene bags. The fungicide was distributed uniformly and posteriorly seeds were placed in container. Ambient air was blown into container, the seal and stirring was performed, aiming at homogeneous distribution of product on seeds.

After spray volume distribution, seeds were placed in order to dry under laboratory conditions for 24 hours at $22^{\circ} \mathrm{C}$. Afterwards, seeds were submitted to seed physiological performance assessment and the following evaluations were performed in the laboratory:

\section{Germination}

Test was performed with four subsamples of 50 seeds for each treatment, placed in polythene boxes of "gerbox" type containing two sheets of blotting paper, wetted in the 2.5 times proportion to the dry weight of paper. Boxes were placed in a BOD at $20^{\circ} \mathrm{C}$. The evaluation of the number of normal seedlings was performed 
on the tenth day after test installation and results were expressed as a percentage (BRASIL, 2009).

\section{First count}

It was performed with the germination test, and the percentage record of normal seedlings which were observed four days after the test installation. Results were expressed as percentage of normal seedlings (BRASIL, 2009).

\section{Emergence and initial growth}

Seeds were placed to germinate in plots containing as substrate soil of A1 horizon classified as Solodic Planosol previously corrected according to soil analysis and based on Fertilization and Liming Manual for the states of Rio Grande do Sul and Santa Catarina. Irrigation was performed when necessary, in order to meet the water demand of plants. Aiming at assessing the vigor expression and initial plant growth were evaluated:

\section{Seedling emergence}

It was evaluated from sowing of four replicates of 50 seeds per treatment, and evaluations were performed at 21 days after sowing and results expressed as a percentage of emerged seedlings.

\section{Emergency speed index}

It was evaluated with the seedling emergence test and determined from daily count of the number of emerged seedlings until process stabilization. The calculation of the emergency speed index was performed by equation proposed Maguire (1962).

\section{and roots}

Leaf area, length and dry mass of shoot

It was determined from four replications of 10 plants per treatment, 30 days after sowing. For leaf area measurement, LI-3100 area meter was used, results were expressed in square centimeters of leaf area $\left(\mathrm{cm}^{-2}\right)$. The shoot length was obtained by determining the distance between the insertions of basal portion of primary root to the shoot apex, while the primary root length was measured by the distance between its apical and basal ends, with the help of a ruler, expressed in centimeters $(\mathrm{cm})$.

To determine the dry matter of roots and shoot, these structures were apart conditioned in brown paper envelopes and submitted to dry in forced ventilation at $70{ }^{\circ} \mathrm{C}$ until constant weight, approximately two days. Values of dry matter of shoot and roots were obtained by precision balanceand results were expressed in grams per organ $\left(\mathrm{g} \mathrm{organ}^{-1}\right)$.

\section{Leaf area ratio}

It was estimated by equation $F_{a}=A_{f} / W_{t}$, wherein $A_{f}$ corresponds to leaf area and $W_{t}$ indicates the plant total dry weight. Results were expressed in centimeters per gram $\left(\mathrm{cm} \mathrm{g}^{-1}\right)$. While shoot and root ratio was determined from the equation $\mathrm{P}_{\mathrm{w}}=\mathrm{W}_{\mathrm{pa}} / \mathrm{W}_{\mathrm{r}}$, where $\mathrm{W}_{\mathrm{pa}}$ refers to the dry matter allocated on shoot and $W_{r}$ indicates dry matter allocated on roots.

\section{Statistical analysis}

The experimental design was completely randomized in a factorial $3 \times 4$ (three lots - high, medium and low vigor $x$ four fungicide doses of carboxin + thiram). Data were submitted to analysis of variance and if significant at 5\% probability, adjusted for orthogonal polynomials by software SISVAR (FERREIRA, 2003).

\section{Results and Discussion}

The carboxin + thiram fungicide, regardless of dose, provided changes in physiological performance of seeds and red clover plants, with interaction between lots and doses (Figures 1, 2 and 3).

The lot of seeds with high vigor showed no increase in germination with the use of fungicide (Figura 1a), maintaining the marketing standards above 70\% (BRASIL, 2005). However, seed of lots with medium and low vigor had increased germination by applying seed treatment, with maximum response reached at doses of 195.25 and $191.0 \mathrm{~mL}$ i.a./100 kg of seeds $\mathrm{mL}$ i.a./100 (Figure 1a). Seed quality is determined in field (PESKE et al., 2012), however, in forage species with possible contamination by pathogens, the attributes of germination process can be enhanced by chemical treatment of seeds (LASCA et al., 2006).

According to Gomes et al. (2009) seeds with high vigor do not show obvious results against the chemical treatment, while those of medium vigor may discreetly respond. Bittencourt et al. (2007) by studying carboxin + thiram efficiency in peanut seeds observed that seeds with $52 \%$ of germination when using doses of carboxin + thiram of $50+50$ and $70+70 \mathrm{~mL}$ i.a. / $100 \mathrm{~kg}$ of seeds showed increase in percentage of germinated seeds to $78 \%$, showing a positive response on the quality of seeds to the used doses.

In the first germination count, seeds of lot with high vigor showed increase in values until the dose of $147 \mathrm{~mL}$ i.a. $/ 100 \mathrm{~kg}$ of seeds, while seeds of medium vigor lot decreased until the dose of $204.8 \mathrm{~mL}$ i.a. $/ 100 \mathrm{~kg}$ of seeds and the 
low vigor lot showed a declining trend (Figure 1b).

The results obtained for first germination allow evidence that high vigor seeds showed better response in terms of vigor when determined by the first germination count, while those from low vigor lot, demonstrated negative effect of seed treatment with the combination of carboxin + thiram fungicide.

Figure 1. Germinaton (a), first germination count (b), emergency (c) emergence speed index (d) of red clover seedlings under influence of fungicide concentration of carboxin + thiram. Capão do Leão, RS. 2018. *significant at $5 \%$ probability. (O) Lot with high vigor; (O) Lot with medium vigor; $(O)$ Lot with low vigor.
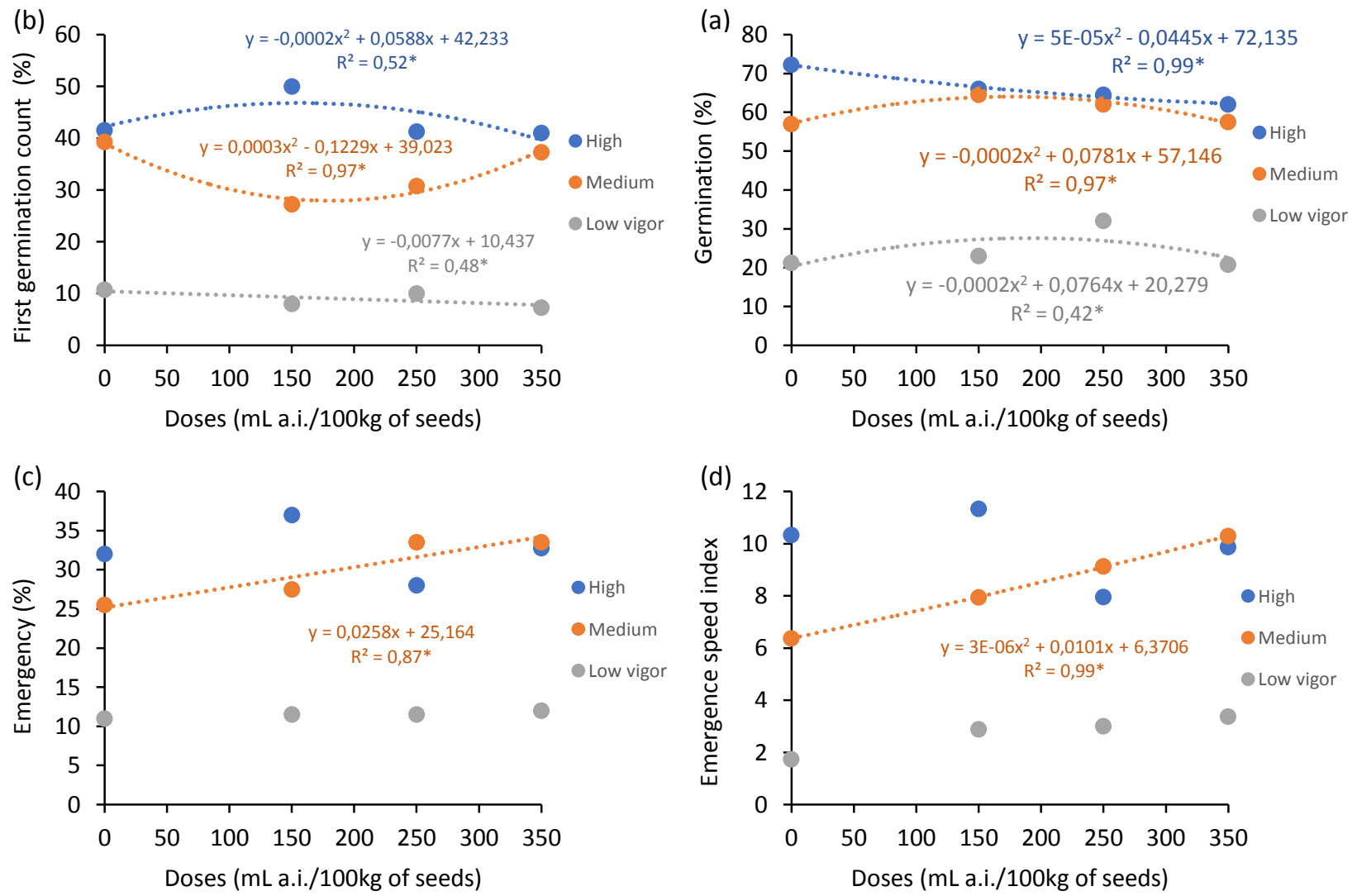

Thus, it should be noted that seeds with greater vigor are more efficient in physiological processes of reserve mobilization and reorganization of membranes, and also respond better to environmental conditions, especially under adverse conditions (HENNING et al., 2010). In addition, seeds with greater vigor tend to have higher tolerance to chemical treatment (CARVALHO; NAKAGAWA, 2012), as verified for this variable and red clover seeds.

The seedling emergence and emergence speed index showed significance only for seeds of medium vigor lot (Figure 1c and 1d). REZENDE et al. (2003) worked with soybeans, and state beneficial effect of treatment with fungicide, where, with the use of carboxin + thiram, drought does not affect the initial stand. 
Figure 2. Length of shoot (a), length of root (b), dry matter of shoot (c) dry matter of root (d) of red clover seedlings under influence of fungicide concentration of carboxin + thiram. Capão do Leão, RS. 2018. *significant at $5 \%$ probability. ( Lot with high vigor; ( $\bigcirc$ )Lot with medium vigor; $(\bigcirc)$ Lot with low vigor.
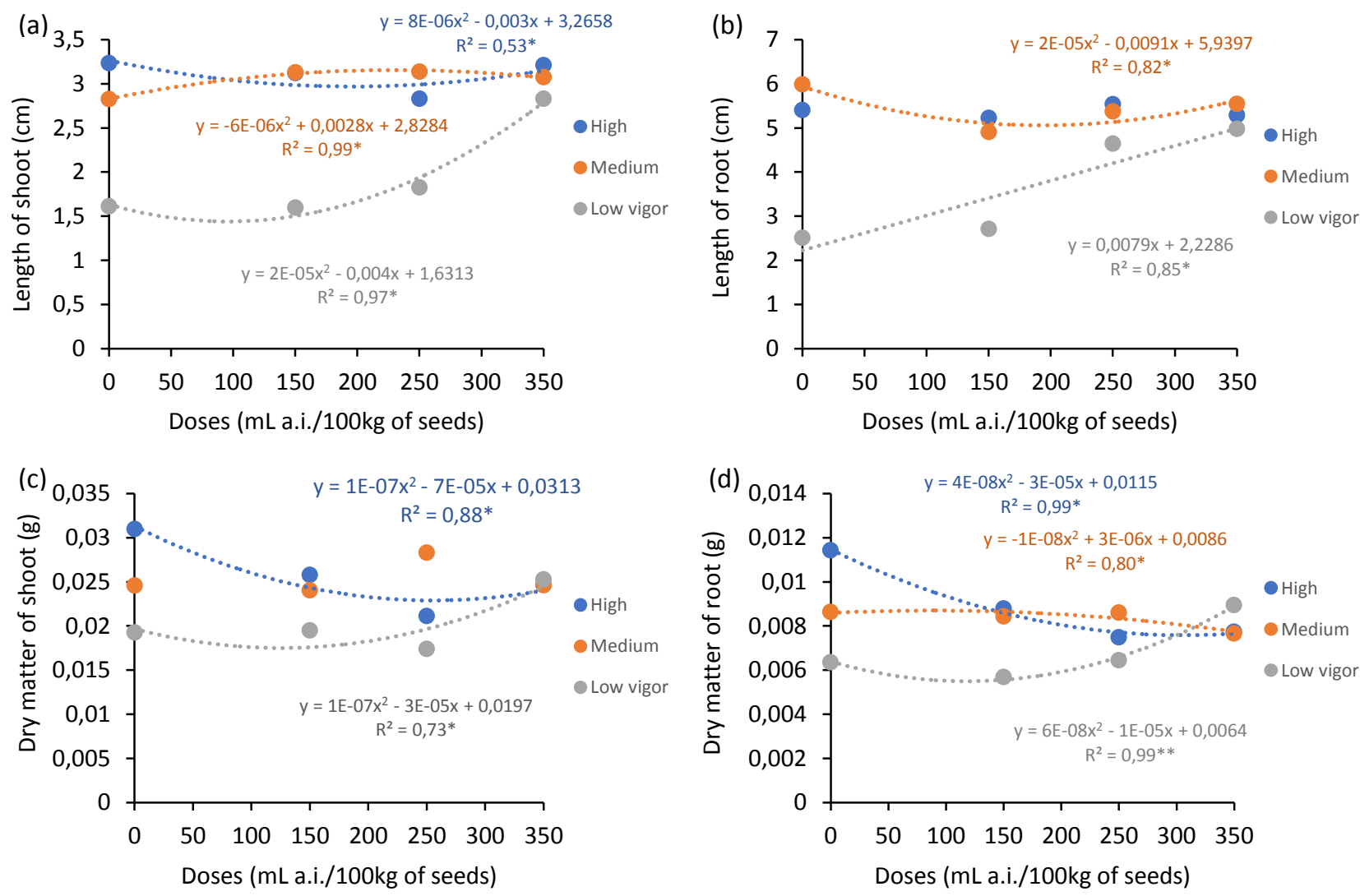

Henning et al. (2010) reported that high vigor seeds originate greater length seedlings compared to lots of low vigor and due to this occurrence, seed with low vigor present reduction in emergency speed, in the production of dry biomass and growth rates of plants, and may affect crop establishment (MELO et al., 2006). High vigor seeds by presenting fast emergence do not respond to fungicide treatment compared to low vigor seeds (CARVALHO; NAKAGAWA, 2012).

The change in the allocation of dry matter in seedlings can be related to the dose of the combination of thiram + carboxin fungicides, being higher in doses above $150 \mathrm{mLi} . a . / 100 \mathrm{~kg}$ of seeds, in seedlings originated from low vigor lot, increasing the dry matter accumulation of shoot and root, which may be related to greater accumulation of sugars in root zone (GONZÀLEZMELER et al., 1999).

The low vigor seeds are more susceptible to adverse environmental conditions and chemical treatment, although beneficial for the plant initial establishment, it is an external agent that can trigger stress to seed or plant. As low

vigor seeds are more sensitive to unfavorable environmental conditions, regardless of stress quantity, it tend to have inferior physiological performance compared to those of medium and high vigor (Figure 2).

The leaf area of plant depends on the number, size of leaves and phenological stage and can also be influenced by the pests attack. Photo assimilated production produced by the first leaves formed from plant has as main target its growth in terms of mass and volume, aiming at forming new leaves for the establishment of a suitable leaf area index (LOPES; LIMA, 2015).

Thus, any factor that reduces leaf area leads to less photo assimilated production therefore, in reduction of plant growth with possible negative effects on development (LOPES; LIMA, 2015).

As noted for the lot of higher vigor, increased carboxim + thiram dose resulted in reduction in leaf area to the point of minimum response on dose of $217 \mathrm{~mL}$ i.a./100 kg of seed (Figure 3a). The change in the amount of leaf area influences leaf area ratio and may limit the carbon fixation process by photosynthesis 
process, due to the impairment of photochemical stage, reducing plant growth (LOPES; LIMA, 2015).

The ratio of leaf area of plants originated of seed lot of high vigor adjusted to the quadratic model with point of minimal response in the dose of $216.80 \mathrm{~mL}$ i.a./100 kg of seeds, with subsequent increasing tendency. However, plants originated from seeds of medium vigor lot showed a linear increase in leaf area ratio values (Figure $3 \mathrm{~b}$ ). In plants of low vigor lot there were indicative of reduced growth in leaf area compared to the total amount of dry biomass produced contributing to the increase in the value of this variable with increased dose of the product.

The leaf area ratio determines the area of usable leaves to the photosynthetic process and relates produced and allocated dry matter in different plant structures with available leaf area, indicating that for each $1 \mathrm{~cm}^{-2}$ of leaf area, there is production of 1 gram of mass dry on plant (BENINCASA, 1988). The leaf area reduction adversely affects the production and distribution of assimilated, reducing growth rates (PEDÓ et al., 2014).

Figure 3. Leaf area (a), leaf area ratio (b), shot/root ratio (c) of red clover seedlings under influence of fungicide concentration of carboxin + thiram. Capão do Leão, RS. 2018. *significant at $5 \%$ probability. (O) Lot with high vigor; ( $\bigcirc$ ) Lot with medium vigor; $(\bigcirc)$ Lot with low vigor.
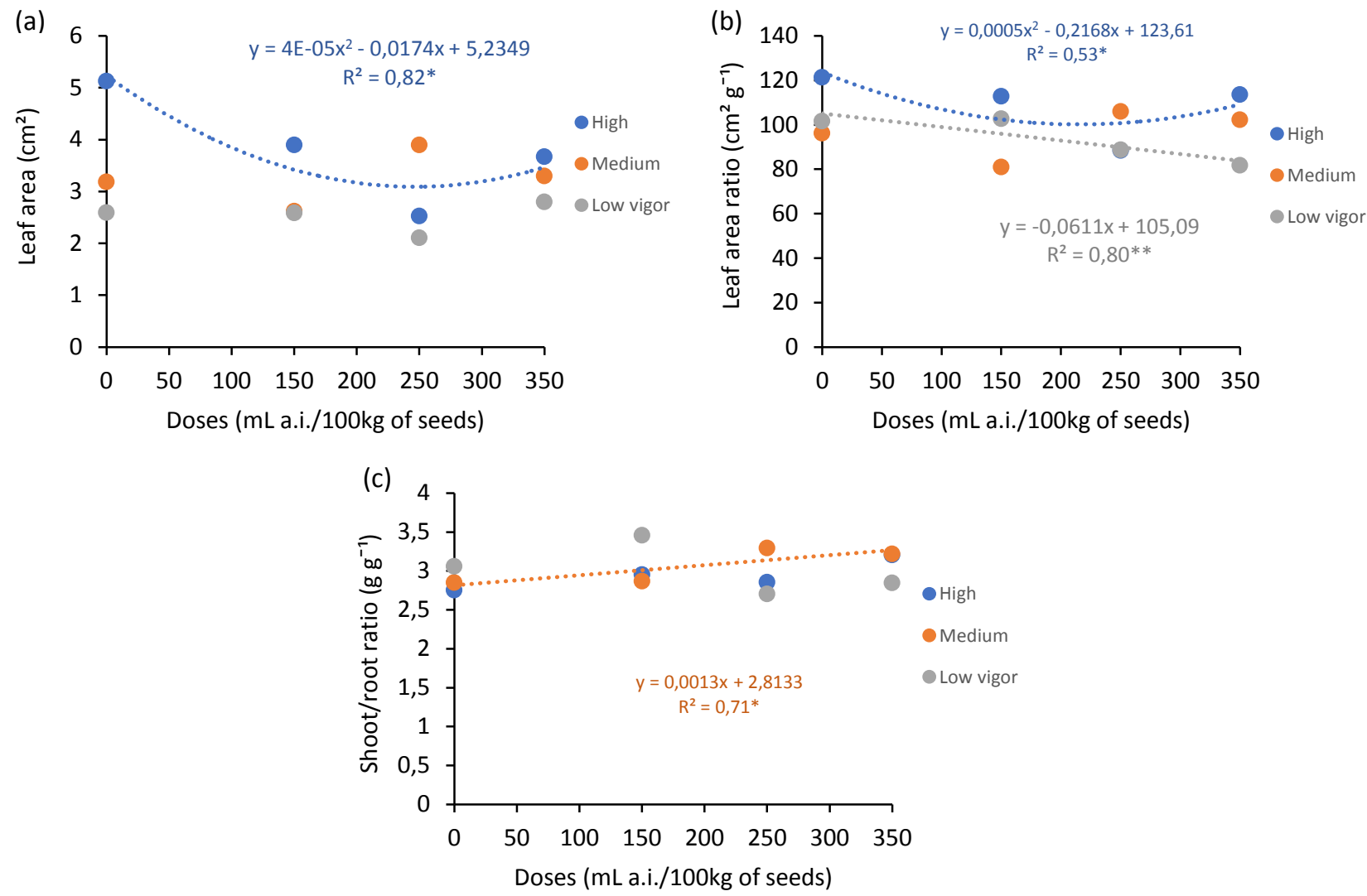

Regarding shoot/roots ratio, there was only significance when considering plants from medium vigor seeds, with increase in the value of this variable to the highest dose of the used product (Figure $3 \mathrm{c}$ ). According to Silva et al. (2007), if there is an increase of this ratio, low metabolic activity on leaves occurs by reducing the production of photo assimilated that would be transferred to roots, because what is produced is maintained in the leaves. If this ratio decreases, there is lower development of root system, and hence lower water absorption, to the detriment with dry mass increase of shoot (CORREA; NOGUEIRA, 2004).

It is noteworthy that the use carboxin + thiram fungicide showed favorable results in germination and initial growth of clover plants. Seed treatment showed evidence of its effectiveness in species seeds.

\section{Conclusions}


The fungicide doses of $150 \mathrm{~mL}$ to $350 \mathrm{~mL}$ i.a./100 kg of seeds result in greater seedling emergence, higher leaf area ratio and increased shoot and root ratio in plants from seed lot of medium vigor.

The carboxin + thiram fungicide enhances expression of seed vigor and growth physiological performance of plants from seed lot of medium vigor.

\section{References}

BAUDET, L.; PESKE, T. S. A logística do tratamento de sementes. SEED News, v.10, n.1, p. 22-25, 2006.

BENINCASA, M. M. P. Análise de crescimento de plantas: noções básicas. Jaboticabal: Fundação de Estudos e Pesquisas em Agronomia, Medicina Veterinária e Zootecnia, 1998.

BITTENCOURT, S.R.M.; MENTEN, J.O.M.; ARAKI, C.A.S.; MORAES, M.H.D.; RUGAI, A.D.; DIEGUEZ, M.J.; VIEIRA, R.D. Eficiência do fungicida carboxin + thiram no tratamento de sementes de amendoim. Revista Brasileira de Sementes, v.29, n.2, p.214-222, 2007. http://dx.doi.org/10.1590/S0101-

\section{8}

BRASIL. Ministério da Agricultura e da Reforma Agrária. Regras para análise de sementes. Brasília: Mapa/ACS, 2009.

BRASIL. Ministério da Agricultura, Pecuária e Abastecimento. Padrões para produção e comercialização de sementes de trevo vermelho. Instrução normativa no 243 , de 20 de dezembro de 2005. Brasília: MAPA/ACS, 2005. 2p.

CARVALHO, N.M.; NAKAGAWA, J. Sementes: ciência, tecnologia e produção. 5. ed. Jaboticabal: FUNEP, 2009.

CORREIA, K.G.; NOGUEIRA, R.J.M. C. Avaliação do crescimento do amendoim (Arachis hypogaea L.) submetido a déficit hídrico. Revista de Biologia e Ciências da Terra, v.4, n.2, 2004. Disponível em: http://www.redalyc.org/pdf/500/50040214.pdf. Acesso em: 09 maio 2018.

FERREIRA, D. F. Programa de análises estatísticas (Statistical Analysis Software) e planejamento de experimentos. Lavras: Departamento de exatas da Universidade Federal de Lavras, 2003. [Software].

FONTANELI, R. S.; FONTANELI, R. S.; SANTOS, H. $P$. Leguminosas forrageiras perenes de inverno. In: FONTANELI, R. S.; SANTOS, H. P.; FONTANELI, R. S. (Eds.) Forrageiras para integração lavourapecuária-floresta na região sul-brasileira. Brasília: Embrapa, 2012. p. 321-334.

GOMES, D. P.; BARROZO, L. M.; SOUZA, A. L.; SADER, R.; SILVA, G. C. Efeito do vigor e do tratamento fungicida nos testes de germinação $e$ de sanidade de sementes de soja. Bioscience Journal, v.25, n.6, 59-65, 2009.

GONZÀLEZ-MELER, M.A.; RIBAS-CARBO, M.; GILES, L.; SIEDOW, J.N. The effect of growth and measurement temperature on the activity of the alternative respiratory pathway. Plant Physiology, v.120, n.3, p.765-772, 1999. http://dx.doi.org/10.1104/pp.120.3.765

HENNING, F. A.; LILIANE MARCIA MERTZ, L. M.; JACOB JUNIOR, E. A.; MACHADO, E. D.; FISS, G.; ZIMMER, P. D. Composição química e mobilização de reservas em sementes de soja de alto e baixo vigor. Bragantia, v.69, n.3, p. 727-734, 2010. https://doi.org/10.1590/S000687052010000300026

LASCA, C. C.; VECHIATO, M. H.; KOHARA, E. Y. Controle de fungos de sementes de Brachiaria spp.: eficiência de fungicidas e influência do período de armazenamento de sementes tratadas sobre a ação desses produtos. Arquivos do Instituto Biológico, v.71, n.4, p. 465-472, 2004.

LOPES, N. F.; LIMA, M. G. S. Fisiologia da produção. Viçosa: UFV, 2015.

MAGUIRE, J. D. Speed of germination: aid in selection and evaluation for seedling emergence and vigor. Crop Science, v.2, n.2, 176-177, 1962. https://doi.org/10.2135/cropsci1962.0011183X0 $\underline{00200020033 x}$

MARCHI, C.E.; FERNANDES, C. D.; VERZIGNASSI, J. R. Doenças em plantas forrageiras. Campo Grande: EMBRAPA Gado de Corte, 2011. 47p. (Documentos; 187). 
MARRONI, I. V.; MOURA, A. B.; UENO, B. Chemical and biological treatments of castor bean seeds: effects on germination, emergence and associated microorganisms. Revista Brasileira de Sementes, v.34, n.1, p. 21-28, 2012.

MELO, P.T.B.S.; SCHUCH, L.O.B.; ASSIS, F.N.; CONCENÇO, G. Comportamento individual de plantas originadas de sementes com diferentes níveis de qualidade fisiológica em populações de arroz irrigado. Revista Brasileira de Sementes, v.28, n.2, p. 84-94, 2006. http://dx.doi.org/10.1590/S0101$\underline{31222006000200011}$

PEDÓ, T.; SEGALIN, S. R.; SILVA, T. A. DA; MARTINAZZO, E. G.; NETO, A. G.; AUMONDE, T. Z.; VILLELA, F. A. Vigor de sementes e desempenho inicial de plântulas de feijoeiro em diferentes profundidades de semeadura. Revista Brasileira de Ciências Agrárias, v.9, n.1, p. 59-64, 2014.

http://dx.doi.org/10.5039/agraria.v9i1a3631

PESKE, S.T.; VILLELA, F.A.; MENEGUELLO, G.E. Sementes: Fundamentos Científicos e Tecnológicos. Pelotas: Ed.Universitária/UFPel, 2012.

REZENDE, P. M.; MACHADO, J. CRUZ.; CRIS, C.F.; GOMES, L. L.; BOTREL, E. P. Efeito da semeadura a seco e tratamento de sementes na emergência, rendimento de grãos e outras características da soja (Glycine max). Ciência e Agrotecnologia, v.27, n.1, p. 76-83, 2003. http://dx.doi.org/doi: 10.1590/S1413-70542003000100009

SILVA, R. R. DA; FREITAS, G. A. DE; SIEBENEICHLER, S. C.; MATA, J. F. DA; CHAGAS, J. R. Desenvolvimento inicial de plântulas de Theobroma grandiflorum (Willd. ex Spreng.) Schum. sob influência de sombreamento. Acta Amazônica, v.37, n.3, p. 365-370, 2007. http://dx.doi.org/10.1590/S0044-

$\underline{59672007000300007}$ 